\title{
Athelia rolfsii (= Sclerotium rolfsii) infects banana in the Philippines
}

\author{
Bienvenido D. Acabal Jr ${ }^{1,2} \cdot$ Teresita U. Dalisay ${ }^{2}$. Johannes Z. Groenewald ${ }^{3} \cdot$ Pedro W. Crous $^{3}$. \\ Christian Joseph R. Cumagun ${ }^{2}$ if
}

Received: 15 February 2019 / Accepted: 9 April 2019/Published online: 26 April 2019

(C) Australasian Plant Pathology Society Inc. 2019

\begin{abstract}
We surveyed eight banana farms planted with cultivar "Lakatan" in Central Visayas, Philippines, for fungal diseases in 2014. A rotting disease on the corm and leaf sheaths, splitting of the pseudostem and yellowing of the leaves were observed only in Toledo City, Cebu province. These symptoms were associated with sclerotial bodies and mycelial growth. The causal organism was identified by morphology and ITS sequence as Athelia rolfsii (= Sclerotium rolfsii) which is the first report of this fungal pathogen on banana from the Philippines.
\end{abstract}

Keywords Banana $\cdot$ Control of spread $\cdot$ Fungal disease $\cdot$ Identification

Banana (Musa sp.) is the leading fresh fruit in the Philippines and eighth most important food crop in the world, fourth in developed countries and fourth most important global food crop grown in more than 120 countries (FAO Report 2003; Anon 2016) and staple food for more than 400 million people (Swennen et al. 1995).

In 2014, a survey for corm rot disease of Musa acuminata cultivar "Lakatan" was conducted at eight plantations spread over Bohol, Siquijor, Negros Oriental and Cebu provinces of the Philippines. A characteristic corm rot disease associated with a Sclerotium-like fungus was detected in one site, namely Toledo City, Cebu province. Based on the characteristic

Electronic supplementary material The online version of this article (https://doi.org/10.1007/s13314-019-0341-x) contains supplementary material, which is available to authorized users.

Christian Joseph R. Cumagun

crcumagun1@up.edu.ph

1 Regional Crop Protection Center, Department of Agriculture-Field Research Unit, DA-MES Complex, City, Mandaue, Philippines

2 Institute of Weed Science, Entomology and Plant Pathology, College of Agriculture and Food Science, University of the Philippines Los Baños College, Laguna, Philippines

3 Westerdijk Fungal Biodiversity Institute, Uppsalalaan 8, 3584, CT Utrecht, The Netherlands disease symptomatology, morphology of the fungus and its ITS sequence, it was identified as Athelia rolfsii (Anamorph: Sclerotium rolfsii) (Tu and Kimbrough 1978), which is a known pathogen of banana and numerous other hosts. The external symptoms of infected banana cultivar"Lakatan" include yellowing of older leaves from the base to apex and pseudostem rot with mycelial growth at the back of sheath. The rotten part has a yellowish-reddish brown colour with sclerotial bodies (Fig. 1). Splitting of the basal portion of the pseudostem sheath was also observed. The average sclerotial body was $1.25 \mathrm{~cm}$ in diameter $(n=100)$ using a digital calliper. A representative culture was deposited in the culture collection of the Westerdijk Fungal Biodiversity Institute (CBS), the Netherlands, under accession number CBS 145328. To confirm the identity of the causal organism, the fungus was identified by ITS sequencing using standard primers and amplification conditions (White et al. 1990; sequence deposited in GenBank under accession number MK411221). The nucleotide sequence was identical over 683 nucleotides (100\%, no gaps) to that of A. rolfsii isolate BOScR-1 (GenBank KJ546416.1 from butterfly orchid in China, unpublished) and differed with one nucleotide (682/683 (99\%), none to a single gap) from numerous other sequences of the same species, e.g. GenBank GU080230.1 (from Capsicum annuum in Spain, Remesal et al. 2010). Pathogenicity tests of $A$. rolfsii were successfully 

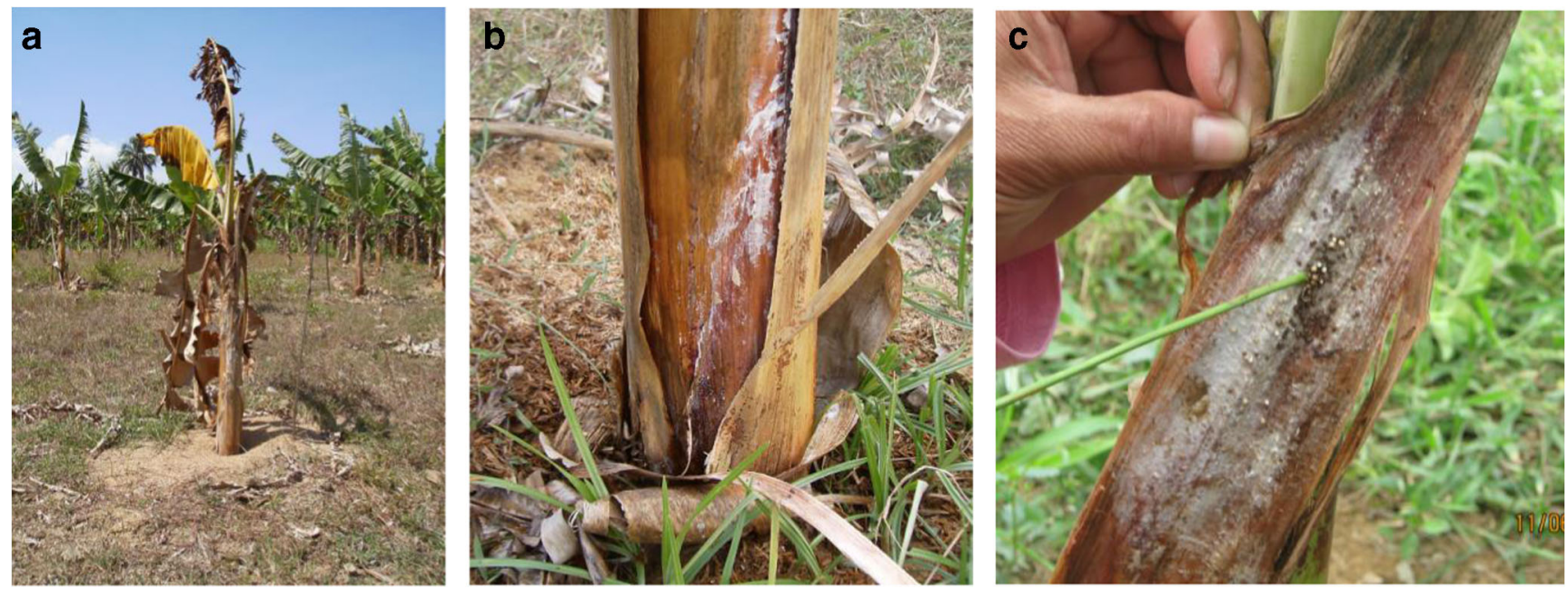

Fig. 1 A. External symptom: yellowing of leaves; B. Mycelia of A. rolfsii on leaf sheath; and C. Sclerotial bodies (mature and young) of A. rolfsii on leaf sheath

conducted under uncontrolled conditions in a glasshouse using both potted 3-month-old tissue-cultured banana cultivar "Lakatan" plants and potted approximately 3-month-old corm bit-cultured banana cultivar "Lakatan" plants with four pots per replication. Sclerotial bodies incorporated in the soil and covered with dried banana leaf was found effective for A. rolfsii inoculation. At two weeks post inoculation, A. rolfsii was observed to have affected the leaf sheaths of inoculated plants, and to have produced sclerotial bodies (Fig. 2). The pathogenicity test was repeated twice. Symptoms observed on inoculated banana plants were similar to those observed on naturally infected plants. The pathogen was re-isolated in subsequent experiments, thus proving Koch's postulates. Athelia rolfsii was reported in the Philippines as early as 1918 in rice (Reinking 1918), tomato, peanut (Fajardo and Mendoza (1935), cotton (Celino 1936),
Impatiens sultanii (Dizon and Pimentel 1993), pepper, mungbean and soybean (de la Cueva 1994), but not yet on banana. This is the first record of $A$. rolfsii on banana from the Philippines.

As a banana exporting country, Filipino farmers need to be aware of this newly reported disease that can be easily disseminated by infected banana plantlets due to the soil-borne nature of A. rolfsii. With reports of the devastation of the disease in enset in an experimental station in Ethiopia (Jones 2019) and in different banana growing states in India (Thangavelu and Mustaffa 2010), it could also have serious implications on the Philippine banana export industry. So far, no spread of the disease to adjacent areas has been observed, but the incidence has been reported both during wet and dry season. To further help contain the disease, a resistant banana cultivar "Cardaba" has been planted around the Sclerotium infested area.
Fig. 2 Pathogenicity test. A. banana cultivar "Lakatan" inoculated with A. rolfsii and B. Healthy banana cv. "Lakatan"
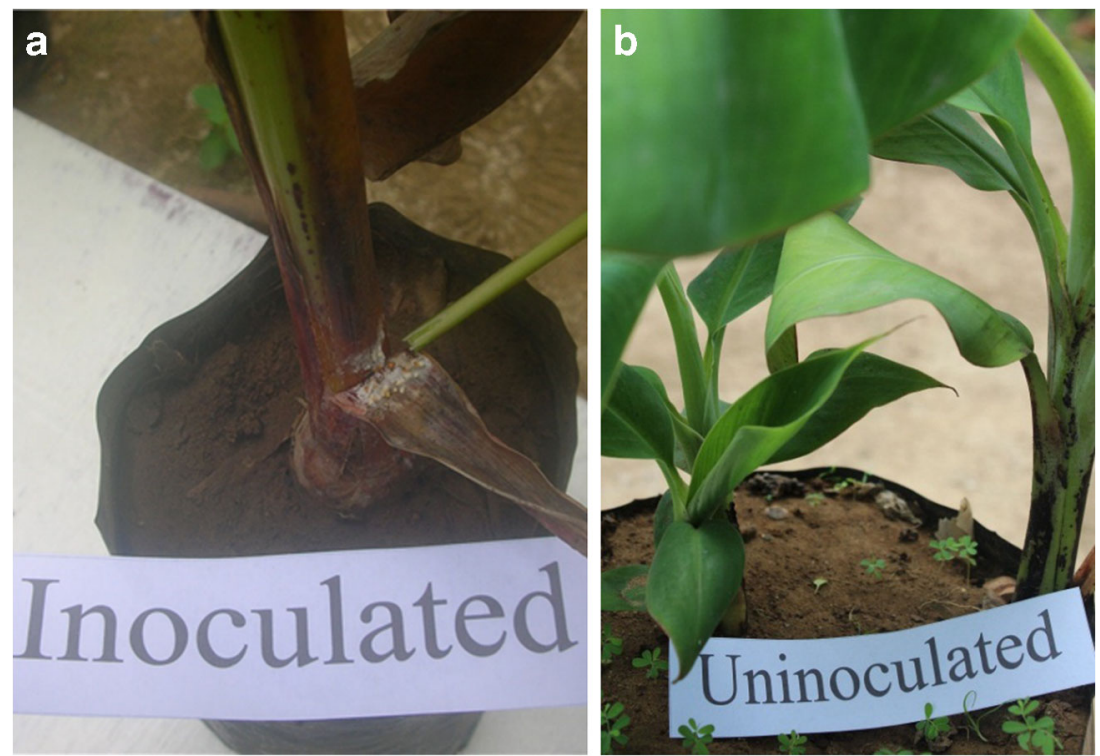
Acknowledgements The authors would like to thank the Department of Agriculture - Bureau of Agricultural Research (BAR), Philippines for funding and support.

\section{References}

Anon (2016) The Biology of Musa L. (banana) Version 2 (2016) Department of Health and Ageing Office of the Gene Technology regulation. Australian Government. http://www.ogtr.gov.au/internet/ogtr/ publishing.nsf/content/5DCF28AD2F3779C4CA257D4E001819B9/ \$File/biologybanana2016.pdf. Accessed January 25, 2019

Celino MS (1936) Diseases of cotton in the Philippines: I. Sclerotium stem rot, with notes on other diseases. Philipp Agric 25:302-320

de la Cueva FM (1994) Cultural, morphological and pathological variation of Sclerotium rolfsii isolated from different crops. Phil J Crop Sci Suppl 1:26

Dizon TO, Pimentel RB (1993) Phytopathological note: Impatiens sultanii host of Sclerotium rolfsii and Meloidogyne incognita. Phil Phytopath 29:101-102

Fajardo TG, Mendoza JM (1935) Studies on the Sclerotium rolfsii Sacc. Attacking tomato, peanut and other plants in the Philippines. Phil J Agric 6:387-424
FAO (2003) The World Banana Economy 1985-2002.:http://www.fao. org/docrep/007/y5102e/y5102e00.htm\#Contents. Accessed January 25,2019

Jones DR (2019) Handbook of diseases of banana, abaca and enset. CABI Publishing, Wallingford, $\mathrm{p} 240$

Reinking OA (1918) Philippine economic plant diseases. Philippine Journal of Science 13:228

Remesal E, Lucena C, Azpilicueta A, Landa BB, Navas-Cortes JA (2010) First report of southern blight of pepper caused by Sclerotium rolfsii in southern Spain. Plant Dis 94:280. https://doi.org/10.1094/PDIS94-2-0280C

Swennen R, Vuylsteke D, Ortiz R (1995) Phenotypic diversity and patterns of variation in west and central African plantains (Musa spp., AAB group Musaceae). Econ Bot 49:320-327

Thangavelu R, Mustaffa MM (2010) First report of corm rots disease caused by Sclerotium rolfsii in banana. Aust Plant Dis Notes 5:30-33

Tu CC, Kimbrough JW (1978) Systematics and phylogeny of fungi in the Rhizoctonia complex. Bot Gaz 139:454-466

White TJ, Bruns T, Lee S, Taylor J (1990) Amplification and direct sequencing of fungal ribosomal RNA genes for phylogenetics. In: Innis MA, Gelfand DH, Sninsky JJ, White TJ (eds) PCR protocols. A guide to methods and applications. Academic Press, San Diego, pp 315-322 